Mediterranean Journal of Humanities mjh.akdeniz.edu.tr IV/1, 2014, 53-62

\title{
Disability in Turkey: The Risks in Being Disabled for Accessing Educational Opportunities
}

\author{
Türkiye'de Engellilik: \\ Eğitim Olanaklarına Erişme’de Engelli Olmanın Riskleri
}

Özgür ARUN*

\begin{abstract}
Types of impairments are determined by societal perceptions as to what is outside of the 'normal' (such as having poor health) and not 'ideal' (such as being female). Can it be said that these preconceptions internalized by Turkish society are systemically formed? The objective of this study is to explore the types of obstacles that impede the individual's participation in societal life within the framework mentioned above through analysing the latest data obtained from TurkStat. Analyses indicate that one of the two types of obstacles individuals face in Turkey is physical impairment, the other is gender. Once obstacles stemming from health conditions are considered together with those related to gender within the field of education, opportunities related to visibility in and integration within the public sphere can be turn understand to be both severely and systemically limited for individuals.
\end{abstract}

Keywords: Disability, Education, Gender, Turkey, Correspondence Analysis

Öz: Türkiye'de bireyi engelleme biçimleri, önce bireyin normalin dışına çıktığı durumlara -örneğin sağlıklı olup olmamasına- daha sonra ise geleneksel yapı içerisinde kıymet verilmeyen kategorilere -örneğin kadın olup olmamasına- göre belirlenmektedir. Türkiye için içselleştirilmiş bu ön kabullerin sistematik olarak gerçekleştiği söylenebilir mi? Bu çalışma, Türkiye'de bireyin toplumsal yaşama katılımının hangi biçimlerde engellendiğini, 2002 yılında, Türkiye İstatistik Kurumu tarafından gerçekleştirilen Türkiye Özürlüler Araştırması verilerini analiz ederek okumaya çalışmaktadır. Analizler engelli bireylerin ve kadınların eğitim olanaklarına ulaşamadığını ortaya koymaktadır. Sağlıklı olup olmamaya dayalı olarak, eğitim alanında gerçekleşen engellenme biçimi üzerine toplumsal cinsiyet de eklenince Türkiye'de bireylerin kamuya çıkma olanakları daha da kısıtlanmaktadır.

Anahtar sözcükler: Engellilik, Eğitim, Toplumsal Cinsiyet, Türkiye, Mütekabiliyet Analizi

\section{Introduction}

In which primary fields of societal life do individuals having disabilities face obstacles to meaningful social participation? Ironically, when individuals who are disabled are prevented from functional and social participation but are compelled to survive with these impediments, they are referred to as the disabled (People may be disabled by physical, intellectual or sensory impairment, medical conditions or mental illness. Such impairments, conditions or illnesses may be permanent or transitory in nature. http://www.un.org/esa/socdev/enable/dissre01.htm, 27.10.2006) In a world established to ensure the survival of the non-disabled majority, individuals

\footnotetext{
* Doç. Dr., Akdeniz Üniversitesi, Edebiyat Fakültesi, Gerontoloji Bölümü, Antalya, arun@akdeniz.edu.tr
} 
incapable of fulfilling certain functions have been excluded mentally, linguistically and spatially over the course of time, in addition to being considered revolting in appearance in the eighteenth century and called the fruits of the devil in the Medieval Ages (Tufan, 2006). These bodies/ individuals, in the minds, lingua and spaces of a given time have been described as personae non grata and their expulsion from society has been demanded in words derived from the semantic usage of evil because they were perceived as being the undesirable elements of humanity. A well-known example of this mindset manifested itself in the murders of many in the gas chambers by the Nazis during World War II.

In the context of our analysis, impairment is not embedded in an individual's body, soul or mental functions. Instead, individuals are placed in the "state of disability" because of "the peculiarities" of their bodies and minds, as a result of which they are unable to meet the demands of ordinary life. According to the official definition (Disabled are those who have lost their physical, mental, spiritual, emotional and social abilities to some extent and, thus, are not able to meet appropriately the necessities of ordinary life as a result of inborn or subsequent disorder or accident. http://www.ozida.gov.tr/arastirma/tr_ozurluler_arastirmasi/aciklama.pdf, in the page x (Prime Ministry Administration for Disabled People, 02.10.2009).) in Turkey, these individuals are categorized as "disabled" only because they exhibit a demonstrable loss of social abilities.

Nonetheless, this official definition is not sufficient to show that individuals in Turkey face significant obstacles in daily life. On the contrary, evidence that individuals are limited is implicit in the data of the study conducted with the support of the Prime Ministry's Administration for Disabled People, the Turkish Statistical Institute (TurkStat) and The Scientific and Technological Research Council of Turkey (Tubitak).

It is clear that individuals and their bodies encounter obstacles because of an incompatible structure around them. To call the individual making an effort to actively participate in the daily routines of life disabled is to short-change them. In Turkey, it is time that we focus upon what environmental structures form impediments to active participation in ordinary life instead of addressing the nature of the individuals' bodies and their disabilities as the reason why they cannot participate.

One of the fields in which individuals are frequently prevented from participation in ordinary life in Turkey is education. In this study, I will discuss the role of education as forming one of the obstacles to the individuals participation in ordinary life. More specifically, I will seek an answer to the question: what is the profile of individuals facing obstacles in the field of education?

The goal is to explore the obstacles that the disabled members of Turkish society face and which hinder their ability to fully participate and function within society. It is interested in looking at; (1) how these obstacles are institutionalised and (2) the profile of the disabled individuals that determine the obstacles which they are most likely to face. It is seek to establish whether or not one's health status (being able-bodied vs. being disabled) and gender (being male vs. being female) determines access to education. A question is posed as to whether the "prerequisites" (i.e. being healthy and male) to access education in order to enjoy educational opportunities and enjoy good social standing are not only embedded in Turkish culture, but are also reinforced at institutional levels, especially within the field of education. The obstacles faced by disabled individuals in Turkey in the field of economy, politics, sports, the arts, and academics, etc. might be the object of further research. However the this focus in, this paper is upon education. Therefore in this study education as an institution is investigated, is it structured in such a way that it is itself the obstacle. 


\section{Profile of an Impeded Individual in Turkey}

In 2002, research entitled Turkey Disability Survey was conducted by the Prime Ministry's Administration for Disabled People (Ozida) and the Turkish Statistical Institute (TurkStat) and all households in Turkey were included in the sample, except for those settlements whose population was under 100 inhabitants. Data was collected from 360 thousand households as representative of Turkey's population. The objective of the survey is described as: Many countries including Turkey utilize World Health Organization's (WHO) forecasts because of a lack of statistical information on the disabled population. Countries having development data collection systems obtain relevant information on disabilities from these institutional registries. They also collect information missing in the above records with surveys conducted at regular intervals. In order to fill in information and data gaps in this field, 2002 Turkey Disability Survey was conducted in December, 2002 by the Turkish Statistical Institute in collaboration with the Presidency of The Administration for Disabled People. In this latest and unique survey concerning disability in Turkey, the objective was to determine the number of disabled people, proportion of the disabled, their socio-economic characteristics, their problems in social life, their expectations, the types of impairment, the causes of impairment, and the regional differences, as well as the proportion of population having chronic illnesses.

An initial assessment of the data from the 2002 Turkey Disability Survey allows us to see individuals' profiles according to their impairment. The table below illustrates frequencies of disabilities in Turkey according to gender:

Table 1. The Profile of the Disabled in Turkey

\begin{tabular}{|c|c|c|c|c|c|c|c|c|}
\hline \multirow{2}{*}{\multicolumn{2}{|c|}{ Gender }} & \multicolumn{6}{|c|}{ Types of Impairment } & \multirow{3}{*}{$\begin{array}{c}\text { Total } \\
1039937\end{array}$} \\
\hline & & \multirow{2}{*}{$\begin{array}{c}\mathrm{OOH} \\
416338\end{array}$} & \multirow{2}{*}{$\begin{array}{c}\text { OVI } \\
194816\end{array}$} & \multirow{2}{*}{$\begin{array}{l}\text { OHA } \\
73083\end{array}$} & \multirow{2}{*}{$\begin{array}{l}\text { OTSB } \\
57683\end{array}$} & \multirow{2}{*}{$\begin{array}{c}\text { OMD } \\
139845\end{array}$} & \multirow{2}{*}{$\begin{array}{c}\text { MOD } \\
158172\end{array}$} & \\
\hline & Count & & & & & & & \\
\hline & $\%$ & $40,0 \%$ & $18,7 \%$ & $7,0 \%$ & $5,5 \%$ & $13,4 \%$ & $15,2 \%$ & $100,0 \%$ \\
\hline \multirow{2}{*}{ Female } & Count & 301490 & 139996 & 62493 & 26279 & 92821 & 109288 & 732367 \\
\hline & $\%$ & $41,2 \%$ & $19,1 \%$ & $8,5 \%$ & $3,6 \%$ & $12,7 \%$ & $14,9 \%$ & $100,0 \%$ \\
\hline \multirow{2}{*}{ Total } & Count & 717828 & 334812 & 135576 & 83962 & 232666 & 267460 & 1772304 \\
\hline & $\%$ & $40,5 \%$ & $18,9 \%$ & $7,6 \%$ & $4,7 \%$ & $13,1 \%$ & $15,1 \%$ & $100,0 \%$ \\
\hline
\end{tabular}

OOH: only orthopedically handicapped; OVI: only visually impaired; OHA: only hearing impaired; OTSB: only tongue and speech block; OMD: only mentally disable; MOD: more than one impairments

According to the Turkey Disability Survey of 2002, the types of disabilities females and males have differ. Firstly, the proportional frequency of females who are only orthopedically handicapped (OOH), only visually impaired (OVI) and only hearing impaired (OHA) is higher than their male counterparts (Chi-Square $=5140,9 ; \mathrm{p}<0,05$ ). Secondly, disabilities defined as only tongue and speech block (OTSB), only mental (OMD) and more than one impairments (MOD) are somewhat more frequent amongst males.

The types of disabilities in Turkey are defined by variations in some way, from what society expects to see in the individual (such as being healthy) on the one hand and, on the other, by attributes considered to be superficial by the current form of traditional social structure (such as being female). In Turkey, attitudes of families in general, but in rural areas in particular, tend to 
create and sustain certain values. For example, to attain an education is the pre-condition to save oneself from destitution. Accordingly, to study is, indeed, assessed a high value due to the economic capital which can be accumulated as a result of the act of studying. To save oneself from destitution is in the forefront of family priorities. Consequently, to study is only appreciated under the condition of acquiring an occupation of or a job as a result of it, and that the resulting employment provides economic benefits. In this context, families in Turkey have a tendency to orient their children toward economic rather than social values. In other words, individuals and their actions accrue value only to the extent that economic capital is accumulated through them rather than social and cultural capital. Yet, even though it is usually not verbally expressed, this tendency depends upon two conditions. First, whether the child is male and second, whether s/he is healthy. Given Turkey's paternal heritage, male children are thought to be the heir to the family's property, the carrier of the family name onto future generations and the guarantor of the well-being of family members, especially of the elders in their later years. Therefore, being gainfully employed or possessing an occupation-job becomes highly desirable, having first met the two pre-conditions, of being healthy and of being male (Arun, 2012).

Even then, is it possible to claim that these pre-requisites embedded into Turkish culture are rooted in and sustained by the system? Considering the field of education, when an individual does not meet the criterion of being healthy, is s/he consequently somehow prevented from attaining an education and so with the increased probability of leading an independent life? In addition to health, does gender itself potentially pose an obstacle to attaining an education? The answer may be suggested by the data given in the table below.

Table 2. Educational Conditions as a Precursor to Systematic Selectivity in Turkey

\begin{tabular}{|l|c|c|c|c|c|c|}
\hline \multirow{2}{*}{ Level of Education } & \multicolumn{3}{|c|}{ Population } & \multicolumn{3}{c|}{ Disabled Population } \\
\cline { 2 - 7 } & Frequency & Percent & $\begin{array}{c}\text { Valid } \\
\text { Percent }\end{array}$ & Frequency & Percent & $\begin{array}{c}\text { Valid } \\
\text { Percent }\end{array}$ \\
\hline Non literate & 7764060 & 11,3 & 12,9 & 604945 & 34,1 & 36,3 \\
\hline Literate without diploma & 12037120 & 17,5 & 20,1 & 247642 & 14,0 & 14,9 \\
\hline Elementary School & 21738553 & 31,7 & 36,2 & 549681 & 31,0 & 33,0 \\
\hline Primary Education & 2430754 & 3,5 & 4,1 & 25607 & 1,4 & 1,5 \\
\hline Secondary School & 4499685 & 6,6 & 7,5 & 87257 & 4,9 & 5,2 \\
\hline $\begin{array}{l}\text { Secondary and equal } \\
\text { vocational education }\end{array}$ & 156146 & 0,2 & 0,3 & 3100 & 0,2 & 0,2 \\
\hline High School & 6997669 & 10,2 & 11,7 & 93635 & 5,3 & 5,6 \\
\hline $\begin{array}{l}\text { High School and equal } \\
\text { vocational education }\end{array}$ & 1215056 & 1,8 & 2,0 & 21509 & 1,2 & 1,3 \\
\hline College or Faculty & 3028955 & 4,4 & 5,1 & 30382 & 1,7 & 1,8 \\
\hline MSc/MA, PhD. & 108454 & 0,2 & 0,2 & 1261 & 0,1 & 0,1 \\
\hline Subtotal & 59976452 & 87,4 & 100,0 & 1665018 & 93,9 & 100,0 \\
\hline Unknown/Missing & 8646107 & 12,6 & - & 107286 & 6,0 & - \\
\hline Total & $\mathbf{6 8 6 2 2 5 5 9}$ & $\mathbf{1 0 0}$ & & $\mathbf{1 7 7 2 3 0 5}$ & $\mathbf{1 0 0}$ & \\
\hline
\end{tabular}

(Source: Tufan, \& Arun, 2006)

When the level of education attained by members of the disabled population is compared with their counterparts in the non-disabled cumulative population, it can be asserted that disabled individuals face clear obstacles within the field of education in Turkey. 
According to this data, more than one in four respondents was illiterate and fewer than $31 \%$ of the total population had attained the level of a primary school education or above. As can also be observed from the table, it is a fact that more than half of the population (56.3\%) is barely literate. The major reason for this low level of education is that basic education is mandatory and is supported by the state and after 8 years of elementary compulsory education, continuing onto a higher level of education is optional.

Education in Turkey is regulated by the state. Except for institutions of higher education, all educational establishments are under the control of the Ministry of Education in collaboration with the State Planning Organization. Since the establishment of the Republic of Turkey, special attention has been paid to basic education. Regardless of gender, basic education is mandatory and free and it is guaranteed by constitutional law. In Turkey, primary education for children starts at six or seven years of age, according to the preference of the family, and continues during the next eight years. These first eight years of education, regarded as primary education (first step - elementary school - takes five years and second step - junior high school - is three years) has been mandatory since 1997. High school on the other hand, the next step after compulsory primary education, is not mandatory. Those students who, upon attaining a high school education, wish to go onto university must pass a centralized exam (College Board Exams). Pending centralized exam scores, such students may enter a program of higher education according to their own preferences.

However, the numbers in the above table also illustrate merely rhetoric on one level since it is observed that some individuals, despite the support of the state, remain cut off from educational opportunities. As one focuses on the official statistics presented above, one can see that healthy individuals benefit more frequently from educational opportunities. While $12.9 \%$ of the total population is not literate, $36.3 \%$ of individuals who are handicapped in walking, speaking, seeing, hearing and those that have multiple handicaps cannot acquire even the opportunity to achieve literacy. More specifically, one out of three individuals is not literate among the disabled population. In contrast, this proportion is merely one out of eight in the general population.

In the overall population, the proportion of individuals possessing a high school or equivalent vocational high school diploma is $13.7 \%$. However, only $6.9 \%$ of the individuals who are handicapped in walking, speaking, seeing, hearing and have multiple handicaps have acquired the same level of education. As for having a college or university degree, it almost appears to be an opportunity exclusively available to the healthy. The data confirm that $5.1 \%$ of the general population possesses a university degree while only $1.8 \%$ of individuals defined as disabled have had the opportunity to graduate from a university.

It is evident that, in addition to compulsory basic education, some other factors such as income, location, and social background of the family also play a crucial role in accessing educational opportunities. However, an important parameter which is usually neglected by researchers is that healthy individuals can more readily benefit from these opportunities. Designing educational opportunities with only healthy individuals in mind hinders other individuals from accessing these opportunities. As a result, these other individuals are labelled, according to official descriptions, maladjusted individuals who are not in harmony with the prerequisites of ordinary life. However, that these are individuals who are hindered from access to already limited educational opportunities in the first place, which consequently leaves them "maladjusted" to the needs of daily life. Neither the central government with its policies nor modern tendencies in society to date have been able to eliminate or mitigate these types of obstacles. On the contrary, especially within the existing educational system, the obstacles are 
being perpetuated. Bezmez and Yardımc (2010) argued this issue from a different perspective that "...due to the institutional, political, cultural and historical specificities of Turkey, most non-governmental organizations maintain relations of patronage with state actors. Far from initiating a rights-based discourse, their [people with disabilities] activities cannot be perceived within recent citizenship frameworks" (Bezmez, \& Yardımc1, 2010, 603). Let us take the discussion deeper and focus on the impact of such obstacles through the help of correspondence analysis techniques.

According to the above findings, foremost among the impediments encountered by individuals in Turkey, are those in education. As the issue of gender is considered together with the impairments, these obstacles observed in education are subject to an exponential increase. A social map such as the one below indicates the presence and types of obstacles in education. The social map represents a two-dimensional field, constructed through correspondence analysis (By this technique, it is aimed to describe the associations among variables. Basically, this analysis matches the associations in a frequency table between the rows and columns with each other in a two-dimensional field. Firstly, the profile of the categories -relative frequencies- and masses -marginal proportions- are computed. Then, distances between all these points representing such parameters are calculated, and thus these points are placed in the most appropriate locations inside the two-dimensional field. This analysis tries to present the underlying structure of the data set by following the inductive method -Clausen, 1998-. Findings obtained are presented visually to generate the chart above. For the brief but competent explanation regarding correspondence analysis, -see also Clausen-, 1998 and for more detailed explanation, -Greenacre, \& Blasius, 1994-), where the horizontal axis denotes the level of education and the vertical axis denotes the severity of impairment. For all individuals, the level of education falls going leftward on the horizontal axis. In the chart, two reciprocal sides represent the states of being literate (on the right) and being non-literate (on the left). Accordingly, individuals who are not literate at all are found on the left side while educated individuals, regardless of their educational levels, are found on the right side of the social map. This reciprocity indicates that education is an infallible classifier (Bourdieu, 1986) in societal life. As one moves from left to right along the horizontal plane, where the education dimension is depicted, one observes that the concentration of females falls, that of males rises, while, at the same time, disabilities observed in these individuals are less severe.

Chart 1. The types of obstacles faced by individuals in the field of education in Turkey (correspondence analysis).

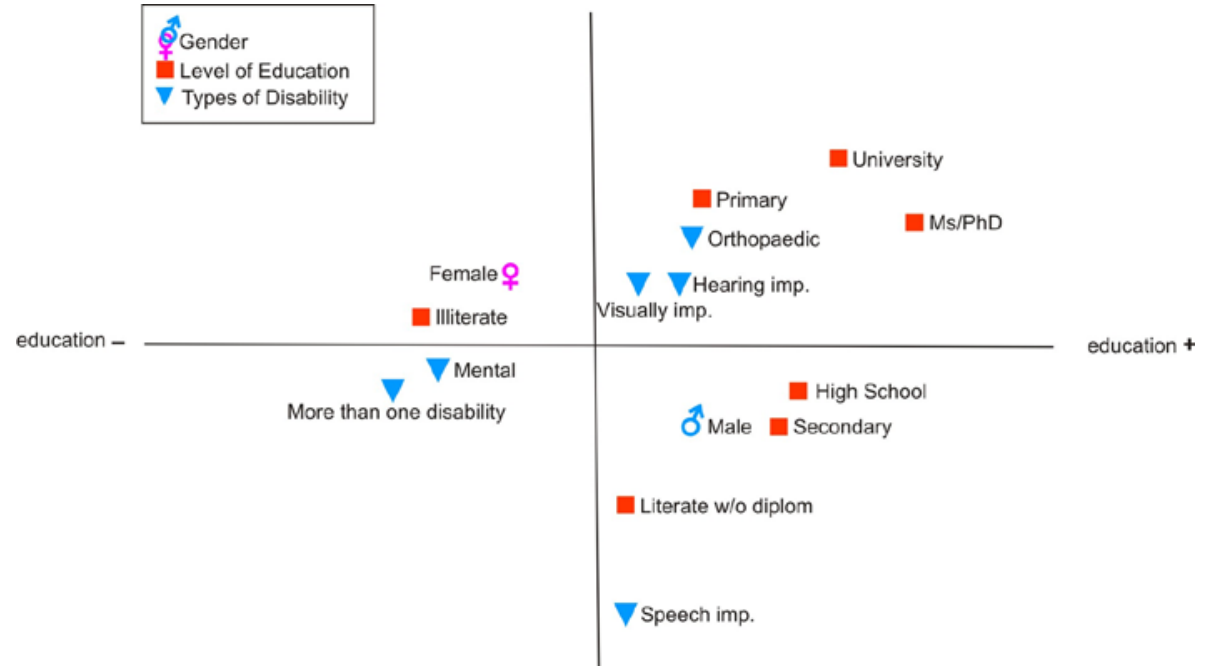


According to the findings of the Turkey Disability Survey 2002, 29.5\% of orthopedically handicapped individuals, $34.9 \%$ of visually impaired individuals, $36.9 \%$ of hearing impaired individuals, $53.1 \%$ of individuals with tongue and speech block, and $66.9 \%$ of mentally disabled individuals are not literate (Tufan, \& Arun, 2006). As it can be observed in Chart 1, those who are mentally disabled and those with more than one impairments differ from other groups in terms of their educational level and are placed together with those in the non-literate category.

In terms of education, the difference between males and females is striking, in that females face more hurdles than their male counterparts. The cluster of hearing, visually impaired and orthopedically handicapped individuals is, relative to other handicapped groups, quite close to those with higher educational levels, although this varies from one handicapped group to another. Ironically, it is also observable that, in the full spectrum of educational levels, individuals who constitute the handicapped group on average were able, at best, to graduate from elementary school, falling far short of being inside the highly educated group.

Another remarkable revelation in respect to the social map provided above is regarding the issue of gender. Individuals' educational opportunities are limited because of some physical and mental differences as mentioned above; however, in addition, when gender is considered, it emerges as another impediment among disabled individuals. Females, regardless of the levels of their impairment have more limitations in accessing educational opportunities than their male counterparts. Females and males appear at opposite sides of the field when it comes to the levels of education and the types of barriers. According to these locations, disabled females have educational opportunities equivalent to those individuals with more than one impairment. This means that while a male who is orthopedically handicapped faces certain barriers in accessing educational opportunities associated with his impairment, his female counterpart faces additional obstacles because of her gender. A disabled female, in this context, faces more than one barrier in the field of education, that is similar to a person with multiple physical/mental disabilities. Accordingly, together with physical and mental disabilities, being female emerges as a barrier to educational opportunities.

Thereby, the tableau interwoven by education, gender and type of impairment above constitutes a status field. At the top of this hierarchy are respectively, firstly, orthopedically handicapped individuals who are the most advantageous of the disadvantaged group, secondly, visually impaired individuals and thirdly, hearing impaired individuals. Individuals whose disabilities differ from these three and those possessing tongue and speech block are classified either as barely literate or illiterate in respect to their educational level. On the other hand, those who have more than one impairment and the mentally disabled are at the bottom of this hierarchy. In this context, the distribution of cultural capital, here gauged by the level of education, shows a similar pattern to the distribution of disabilities. As physical/mental disabilities change to less severe types, and gender changes from female to male, the level of one's education, in other words cultural the capital invested in that individual turns out to be higher.

However, the inequality in the educational levels attained by disabled individuals is an outcome of the absence of educational opportunities specifically set up to meet the needs of these individuals and is not caused by their disabilities.

These barriers hinder progress in societal life and the most effective step to be taken is to neutralize their impact. Mental, spatial and temporal designs which impede the individual's participation in everyday public life as an independent being are the consequence of certain policies, such as bio-policies, that prove destructive to social progress in the long term. 
It is clear that these policies can set into motion state mechanisms for ordering social priorities. Often, a bio-policy "... that is being established is addressed to a multiplicity of men, not to the extent that they are nothing more than their individual bodies, but to the extent that they form, on the contrary, a global mass that is affected by overall processes characteristic of birth, death, production, illness, and so on" (Foucault, 2003, 242-243). What these policies do is to separate the living, from the dying and those who are healthy, from those who are ill. This is done so that their needs as a group can be defined and managed more efficiently from the government's point of view. Deviations from the "healthy" norm regarding the body, mind and from negligible illnesses define these people as disabled individuals who are thus institutionalized, based upon impairment, with the intention of treating them and meeting their aggregate needs.

However, these policies do not deal with people individually to improve their individual status either in the physical sense (the body itself) or in the sense of personal skills and faculties needed to stay connected to society at large. Bio-policies, instead, sequester the disabled and thus diminish opportunities for the rest of society to sustain contact with its disabled members. Moreover, these policies construct predictions based on indicators that primarily reflect the experiences of the majority. To illustrate, implementing a general health security system contributes to longer life spans, even though among the much older there will be those who have severe illnesses and/or disabilities. If this latter group are not separated and counted among the non-healthy individuals it will seem as if the proportion of unhealthy individuals has been reduced, or as if the life span of healthy individuals has increased. This may result in undue systemic emphasis on serving the healthy over a longer lifetime and, not so much on providing for the disabled, whether their disabilities emerge with age or not. This emphasis eventually leads to some balance among the competing goals of the policy, subordinating the goal of serving the disabled minority to serving the healthy majority. Mechanisms are then put into place and coordinated with each other to ensure that the implementation of the system will be done with these same priorities in mind. The result is that the systemic bias becomes well established and is difficult to shift.

\section{Politicised inequality: The risk of being disabled in Turkey}

The discussion above refers to the fact that both traditional insights and institutional structures have a tendency to help create value categories and to sustain them. Although this tendency is not routinely put into words, "value" rests upon two main conditions in Turkey; the first is being male and the second is being healthy. In the institutional meaning, male descendents are thought of as future owners of family properties, propagators of the family name and wardens of family members, especially of its elders. In this case, being gainfully employed or having an occupationjob becomes desirable under the conditions firstly of being healthy and secondly of being male.

In no official document is it written that a physically disabled individual cannot, categorically, benefit from higher education. In principle, individuals who are not able to walk, talk, see, hear and who suffer from more than one of these limitations cannot be separated from their educational rights. However, these findings indicate that these assurances are valid only as rhetoric in Turkey. The fact is that there exist serious impediments to accessing current educational opportunities as is evidenced by official statistics.

To illustrate, in the legislation on education, there is no specific obstacle designed to prevent disabled children from their participation in education. Disabled and non-disabled individuals are seen as equals at the constitutional level. However, for example, the conditions which provide sufficient free movement for a child who is confined to a wheelchair are not present in schools 
in today's Turkey. Barriers are not limited to this; it is possible to cite many physical environments in which individuals are 'disabled' due to the obstacles that otherwise healthy people are not hampered by, such as in traffic, designs for city living, features of vehicles, and the architectural characteristics of instructional facilities.

In general, the unequal distribution of scarce public goods and valuables has persisted over many generations. This inequality in, for example, education, cultivates social hierarchy. On the other hand, in the course of generations, unequal access to education is placing the same types of barriers in the way of the disabled individual, perpetuating the social hierarchy.

The analyses pursued above for the purpose of answering the question as to what types of barriers individuals face -and how they cope- in ordinary life in Turkey also point us to another conclusion: that the system makes the individual monolithic. Living environments have been designed, sometimes implicitly and sometimes explicitly, in such a way that some individuals are excluded from early on in life as a result of being unable to perform various functions required within this design. Therefore, those who remain are those who are similarly healthy and capable of functioning within these environments -i.e. quite a monolithic or standardised community.

Clearly, the obstructions built into the environment are what make the problem chronic. It is both spatially and mentally limiting for individuals with different disabilities and is naturally replicated in future generations. Although the permanency of such a system can be debated, it focuses on the human life cycle and encourages people to be healthy both spiritually and physically while assuming that everyone can and will live up to these ideals.

It is possible to identify evidence supporting this claim through looking at the currently available data. While care and rehabilitation services are acquired by only $5.9 \%$ of disabled individuals, only $10 \%$ of disabled individuals obtain educational services. As for services designed to provide someone with an occupation, consultancy and cultural services were accessed by less than $1 \%$ of the total disabled population (Tufan, \& Arun, 2006, 37.) This indicates that while there is a hierarchy per se among institutions providing these services and within the services themselves, the system's apparatus, which is designed to work as a normalizer of opportunities, has not yet accumulated sufficient experiences that are internalized by society at large. In this context, in Turkey, where we see the mechanisms suggesting that a society whose needs are being managed well is emerging, it must be recognized that they are as yet merely at the beginning of such experiential accumulation.

The research conducted in 2002 was designed for the purpose of informing the comprehensive coordination and mobilization of the mechanisms comprising the system. As well, it helped identify those fields in which individuals in Turkey face the toughest barriers to overcome.

To sum up, one of the two types of obstacles limiting individuals' access to education in Turkey is gender, the other is physical differences. As a result, when physical/mental attributes of a person create a barrier to equal access to educational opportunities, gender (if female) can render that person even less visible and even less integrated within society, thus compounding her impairment. This being the case, differences regarding both gender and physical/mental functions are not merely biological features or common features specific to a given group. On the contrary, these are socially constructed disadvantages and education is playing a leading role in the course of constructing and transmitting such disadvantages from one generation to the next generation at the societal level. 


\section{REFERENCES}

Arun, Ö. (2012). "Cultivated Citizens? Cultural Capital, Class, Gender and Generations in Contemporary Turkey”. METU Studies in Development, Vol. 39 (3), 283-302.

Bezmez, D., \& Yardımc1, S. (2010). "In search of disability rights: citizenship and Turkish disability organizations”. Disability \& Society, Vol. 25 (5), 603-615.

Bourdieu, P. (1986). Distinction: A Social Critique of the Judgement of Taste. London: Routledge \& Kegan Paul Ltd.

Byrne, D., (2002). Interpreting Quantitative Data. London: Sage Publications.

Clausen, S., E. (1998). Applied Correspondence Analysis: An Introduction. Thousand Oaks: Sage Publication.

Daston, L., (2000). "Review of Desrosieres (1998)". London Review of Books, 22 (8).

Foucault, M. (2003). Society Must Be Defended: Lectures at the Collège de France, 1975-76 New York: Picador.

Foucault, M. (1990). The History of Sexuality. New York: Penguin Books.

Greenacre, M., \& Blasius, J. (1994). Correspondence Analysis in the Social Sciences. London: Academic Press.

Marks, J. (2006). "Biopolitics”. Theory, Culture, and Society. 23 (2-3), 333-335.

Tufan, İ. (2006) Engellilik. Webpage of the Disables and Their Friends. http://www.engelliler.biz/ SosyalBakis/engellilik_ismailtufan.htm. 27.10.2006.

Tufan, İ., \& Arun, Ö. (2006). 2002 Turkey Disability Survey, Secondary Analysis. TUBITAK: Project Number: SOBAG-104K077.

Tufan, İ., Yaman, H., \& Arun, Ö. (2007). "Disability in Turkey: Suggestions for Overcoming Current Problems”. International Social Work, Vol. 50 (6), 839-45. 